\title{
Decline in a dominant invertebrate species contributes to altered carbon cycling in a low-diversity soil ecosystem
}

\author{
Byron J. Adams \\ byron_adams@byu.edu \\ J. E. Barrett \\ Ross A. Virginia \\ Diana H. Wall
}

Follow this and additional works at: https://scholarsarchive.byu.edu/facpub

Part of the Microbiology Commons

\section{Original Publication Citation}

Barrett, J. E., Ross A. Virginia, Diana H. Wall, and Byron L. Adams. "Decline in a dominant invertebrate species contributes to altered carbon cycling in a low-diversity soil ecosystem," Global Change Biology 14, 1-11.

\section{BYU ScholarsArchive Citation}

Adams, Byron J.; Barrett, J. E.; Virginia, Ross A.; and Wall, Diana H., "Decline in a dominant invertebrate species contributes to altered carbon cycling in a low-diversity soil ecosystem" (2008). Faculty Publications. 881.

https://scholarsarchive.byu.edu/facpub/881 


\title{
Decline in a dominant invertebrate species contributes to altered carbon cycling in a low-diversity soil ecosystem
}

\author{
J. E. BARRETT*, ROSS A. VIRGINIA $\dagger$, DIANA H. WALL $\ddagger$ and BYRON J. ADAMS§ \\ *Department of Biological Sciences, Virginia Polytechnic Institute and State University, Blacksburg, VA 24061, USA, \\ $\dagger$ Environmental Studies Program, Dartmouth College, Hanover, NH 03755, USA, †Department of Biology and Natural Resource \\ Ecology Laboratory, Colorado State University, Fort Collins, CO 80523, USA, §Department of Microbiology and Molecular Biology, \\ and Evolutionary Ecology Laboratories, Brigham Young University, Provo, UT 84602, USA
}

\begin{abstract}
Low-diversity ecosystems cover large portions of the Earth's land surface, yet studies of climate change on ecosystem functioning typically focus on temperate ecosystems, where diversity is high and the effects of individual species on ecosystem functioning are difficult to determine. We show that a climate-induced decline of an invertebrate species in a low-diversity ecosystem could contribute to significant changes in carbon (C) cycling. Recent climate variability in the McMurdo Dry Valleys of Antarctica is associated with changes in hydrology, biological productivity, and community composition of terrestrial and aquatic ecosystems. One of the greatest changes documented in the dry valleys is a $65 \%$ decrease in the abundance of the dominant soil invertebrate (Scottnema lindsayae, Nematoda) between 1993 and 2005, illustrating sensitivity of biota in this ecosystem to small changes in temperature. Globally, such declines are expected to have significant influences over ecosystem processes such as $C$ cycling. To determine the implications of this climate-induced decline in nematode abundance on soil $\mathrm{C}$ cycling we followed the fate of a ${ }^{13} \mathrm{C}$ tracer added to soils in Taylor Valley, Antarctica. Carbon assimilation by the dry valley nematode community contributed significantly to soil $\mathrm{C}$ cycling (2-7\% of the heterotrophic C flux). Thus, the influence of a climate-induced decline in abundance of a dominant species may have a significant effect on ecosystem functioning in a low-diversity ecosystem.
\end{abstract}

Keywords: Antarctica, carbon cycling, climate change, McMurdo Dry Valleys, nematode, soil biodiversity

Received 13 November 2006; revised version received 21 December 2007 and accepted 25 January 2008

\section{Introduction}

Studies of global change and associated declines in biodiversity have typically focused on macroscopic species in high-diversity ecosystems (e.g. Tilman et al., 2001; Olff et al., 2002; Spehn et al., 2005). Yet, ecosystems with low species and functional diversity may be equally or more vulnerable to global change (Kareiva \& Marvier, 2003; Bohn \& Amundsen, 2004; Newsham \& Garstecki, 2007). Most terrestrial ecosystems host a high degree of redundancy in functional diversity of soil organisms, and it is proposed that losses of individual species will have negligible to low effects on ecosystem processes (Andrén \& Balandreau, 1999), but how the loss of single species may influence functioning in low-

Correspondence: J. E. Barrett, e-mail: jebarre@vt.edu

(C) 2008 The Authors

Journal compilation (C) 2008 Blackwell Publishing Ltd diversity soil ecosystems remains unresolved. For example, in laboratory experiments, the relationship between soil biodiversity and ecosystem functioning is strongest in species-poor communities $(<10$ invertebrate species), but whether these relationships are as important to the functioning of natural systems is less clear (Bradford et al., 2002; Liiri et al., 2002; Setälä \& McLean, 2004).

Quantifying the influences of a specific taxonomic group on soil ecosystems is complicated because of large numbers of species, many unidentified, and multiple interactions among these species (Vetter et al., 2004; Wardle et al., 2004). Such information is essential to develop hypotheses describing the influences of global change on essential ecosystem processes such as carbon (C) cycling (Fitter et al., 2005). The study of low-diversity soil ecosystems such as hot and cold 
deserts may offer opportunities for elucidating relationships between biodiversity and ecosystem functioning (Wall \& Virginia, 1999). Soil ecosystems in the McMurdo Dry Valleys of Victoria Land, Antarctica, comprise simple food webs with minimal diversity and little trophic redundancy (Freckman \& Virginia, 1997; Adams et al., 2006). Hence, the dry valleys provide a model lowdiversity ecosystem for evaluating the importance of individual microscopic soil species in regulating ecosystem functioning.

Climate change in the Antarctic provides opportunity to evaluate the influences of climate variation on the structure and functioning of whole soil communities, where soil food webs are simple relative to temperate or even many Arctic ecosystems (Wall \& Virginia, 1999; Convey \& McInnes, 2005). In contrast to the Antarctic Peninsula and sub-Antarctic which have experienced significant warming over the past 50 years (Vaughan et al., 2003; Turner et al., 2005; Anisimov et al., 2007), the McMurdo Dry Valley region has cooled significantly since the mid-1980s at a rate of $0.07^{\circ} \mathrm{C}$ annually; more relevant to ecological functioning in this region is a

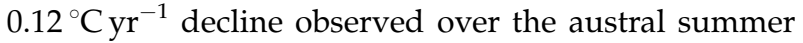
(Doran et al., 2002b). This climate variation is associated with changes in species composition, population levels, and ecosystem functioning in soils, lakes, and streams; soil nematodes in particular exhibited a marked decline (Doran et al., 2002b; Esposito et al., 2006).

To determine the implications of this climate-induced decline in nematode abundance, we investigated $\mathrm{C}$ cycling in Antarctic soil food webs, using an isotope tracer experiment and measurements of soil $\mathrm{CO}_{2}$ efflux in light of long-term variation in nematode communities and soil temperatures at two sites in Taylor Valley, Antarctica (Fig. 1). We assessed the influence of soil biota on the soil $\mathrm{C}$ cycle by measuring the ${ }^{13} \mathrm{C}$ content of soil nematodes following the addition of a ${ }^{13} \mathrm{C}$-labeled

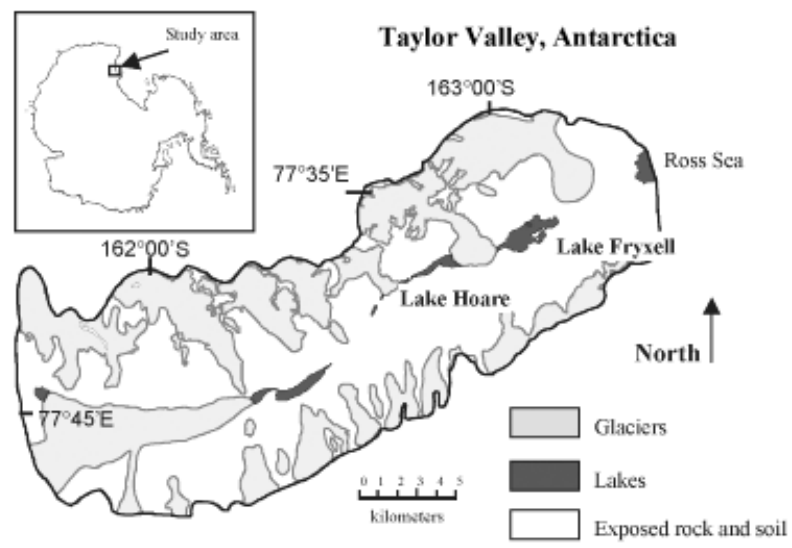

Fig. 1 Location of study sites near Lake Fryxell and Lake Hoare in Taylor Valley (inset), Antarctica. sugar added to intact soil plots. We compared the amount of ${ }^{13} \mathrm{C}$ in living nematodes from pretreatment, tracer-amended, and control soils and calculated the total $\mathrm{C}$ flux through the nematode biomass using assimilation parameters from a food web model (Hunt et al., 1987; Hunt \& Wall, 2002) and related this to observed rates of soil respiration. Our objectives were to estimate the contributions of one- and two-species communities to the total heterotrophic soil $\mathrm{C}$ flux and develop hypotheses predicting the ecosystem-level implications of nematode community shifts following climate change.

\section{Materials and methods}

\section{Study site}

The McMurdo Dry Valley region of Victoria Land, Antarctica, is a polar desert with mean annual temperatures ranging from -15 to $-30^{\circ} \mathrm{C}$ and annual precipitation of less than $10 \mathrm{~cm}$ water equivalent per year (Doran et al., 2002a; Witherow et al., 2006). Terrestrial communities lack vascular plants and other taxonomic groups common to nearly all other soils; metazoan biodiversity is limited to two mite, one springtail, two rotifer, two tardigrade, and four nematode species that rarely co-occur (Barrett et al., 2004; Adams et al., 2006). The most abundant and widely distributed invertebrate is a microbial-feeding nematode, Scottnema lindsayae Timm, 1971, which is often the sole metazoan invertebrate species in soils (Freckman \& Virginia, 1997; Barrett et al., 2004). An additional nematode, Eudorylaimus antarcticus Steiner, 1916 (Yeates, 1970), has a more limited distribution, low abundance, and cooccurs with $S$. lindsayae (along with Plectus spp. and occasionally Geomonhystera spp.) in suitable soil habitats (Treonis et al., 1999; Adams et al., 2006). Multiple factors influence habitat suitability and, therefore, the distribution of soil organisms and the composition of invertebrate communities in the dry valleys, especially salt content and composition, proximity to liquid water, and the availability of organic substrate to fuel metabolic activity (Freckman \& Virginia, 1997; Treonis et al., 1999; Barrett et al., 2004, 2006; Poage et al., 2008).

\section{Nematode abundance and soil environment}

We present multiple year records of soil nematode populations from control plots of long-term soil experiments located near Lake Fryxell and Lake Hoare in Taylor Valley, Antarctica, associated with the McMurdo Long-Term Ecological Research (MCM-LTER) project (Fig. 1, Table 1). Data are presented from a long-term experiment located on the south side of Lake Hoare, including samples ( $n=8$ samples per year) collected between 1993 and 2005 (nematode abundances from 
Table 1 Average soil properties for study sites near Lake Fryxell and Lake Hoare

\begin{tabular}{|c|c|c|c|}
\hline & Fryxell & Hoare & $P(T<t)^{*}$ \\
\hline Location & $77^{\circ} 36^{\prime} 30^{\prime \prime}, 163^{\circ} 14^{\prime} 55^{\prime \prime}$ & $77^{\circ} 38^{\prime} 03^{\prime \prime}, 162^{\circ} 52^{\prime} 50^{\prime \prime}$ & - \\
\hline Elevation (m a.s.1.) & 20 & 80 & - \\
\hline Degree hours above $0^{\circ} \mathrm{C}$ for January 2003 & 584 & 627 & - \\
\hline Soil moisture content $\left(\% \mathrm{~kg} \mathrm{~kg}^{-1}\right)$ & $4.31 \pm 2.61 \dagger$ & $0.64 \pm 0.26$ & 0.026 \\
\hline Conductivity $\left(\mu \mathrm{S} \mathrm{cm}^{-1}\right)$ & $82.1 \pm 13.3$ & $38.7 \pm 16.1$ & 0.0024 \\
\hline $\mathrm{pH}$ & $9.47 \pm 0.22$ & $9.46 \pm 0.28$ & 0.41 \\
\hline Soil organic $\mathrm{C}$ content $\left(\mathrm{gC} \mathrm{kg} \mathrm{soil}{ }^{-1}\right)$ & $0.51 \pm 0.10$ & $0.27 \pm 0.11$ & 0.022 \\
\hline Microbial biomass C (mg C kg soil $\left.{ }^{-1}\right)$ & $8.2 \pm 5.7$ & $7.9 \pm 6.0$ & 0.19 \\
\hline Chlorophyll $a$ content $\left(\mathrm{mg} \mathrm{C} \mathrm{kg} \mathrm{soil}^{-1}\right)$ & $15.6 \pm 8.4$ & $1.1 \pm 0.21$ & 0.087 \\
\hline Total viable Scottnema lindsayae (no. of organisms kg ${ }^{-1}$ ) & $861 \pm 225$ & $247 \pm 54$ & 0.0052 \\
\hline Total viable Eudorylaimus antarcticus (no. of organisms kg ${ }^{-1}$ ) & $117 \pm 56$ & $16 \pm 10$ & 0.019 \\
\hline Frequency of S. lindsayae occurrence & 1.0 & 1.0 & - \\
\hline Frequency of E. antarcticus occurrence & 0.6 & 0.4 & - \\
\hline Total soil C efflux $\left(\mu \mathrm{mol} \mathrm{CO} \mathrm{m}^{-2} \mathrm{~s}^{-1}\right)$ & $0.15 \pm 0.10$ & $0.04 \pm 0.02$ & $<0.0001$ \\
\hline
\end{tabular}

*Significance of differences (one-tailed Student's $t$-test) in soil properties from the Fryxell and Hoare sites.

$\dagger$ Mean \pm 1 standard deviation values are presented for all data.

1993 to 1998 were previously reported in Doran et al., 2002b). Additional nematode data are presented from soil samples ( $n=6$ samples per site per year) collected from control plots between 1999 and 2005 from a complementary experiment located on the south sides of Lake Hoare and Lake Fryxell.

Soils were collected from the top $10 \mathrm{~cm}$ of the soil profile, using aseptic techniques and transported to the Crary Laboratory at McMurdo Station for analyses of soil biotic and chemical properties. Soil nematodes were extracted within $48 \mathrm{~h}$ of sample collection using a modified sugar-centrifugation extraction technique and identified and enumerated under light microscopy (Freckman \& Virginia, 1997). Nematode population abundances are expressed as individuals per $\mathrm{kg}$ soil, corrected to oven dry weight equivalent. Gravimetric soil water content and oven dry weight equivalence were determined from mass loss of soils heated to $105^{\circ} \mathrm{C}$ for $48 \mathrm{~h}$ (Barrett et al., 2004). Soil pH and electrical conductivity were determined using standard electrochemical techniques (Nkem et al., 2006). Soil organic C content was determined on dried, ground, and acidified sub-samples with a Carlo Erba $1500 \mathrm{CHN}$ analyzer (CE Elantech, Lakewood, NJ, USA) at Dartmouth College (Barrett et al., 2004). Microbial biomass was estimated from chloroform labile $\mathrm{C}$ in $0.5 \mathrm{M} \mathrm{K}_{2} \mathrm{SO}_{4}$ extracts following chloroform fumigation and extraction of soils (Cheng \& Virginia, 1993). Total organic C content of control and fumigated $\mathrm{K}_{2} \mathrm{SO}_{4}$ extracts was measured on a Shimadzu 5000 TOC analyzer (Shimadzu, Columbia, MD, USA) in the Crary Analytical Laboratory at McMurdo Station. Chlorophyll $a$ content of soils was determined using an acetone extraction procedure as an index of soil algal biomass (Barrett et al., 2004). Chlor- ophyll $a$ concentrations in the acetone extracts were measured on a Turner Model 111 Fluorometer (Turner Designs, Sunnyvale, CA, USA) in the Crary Analytical Laboratory at McMurdo Station.

We analyzed temperature records from long-term monitoring sites on the south side of Lake Hoare near one of the long-term experimental plots and installed temperature sensors at the Lake Fryxell site. Soil temperature on the south side of Lake Hoare site has been monitored continuously since 1995 using a Campbell CR10XT data-logger (Campbell Corporation, Logan, UT, USA) and thermocouples buried at three depths (surface, $5 \mathrm{~cm}$, and $10 \mathrm{~cm}$ depths). Soil temperatures are logged every $30 \mathrm{~s}$, averaged, and stored at 10-min intervals at this site. At the Lake Fryxell site, soil temperatures were monitored using a HOBO 4-channel outdoor temperature logger (Onset Corporation, Pocasset, MA, USA), recording at 10-min intervals throughout the month of January 2003 to coincide with the in situ tracer experiment. We present the mean annual December, January, and February (DJF) temperatures at $5 \mathrm{~cm}$ depth for the long-term record from the Hoare site (Fig. 2a), and the running 10-min mean temperature at $5 \mathrm{~cm}$ depth for the month of January 2003 at the Lake Hoare and Lake Fryxell sites (Fig. 2b) to depict interannual, seasonal, and diel variations in soil microclimate. These data are used to estimate number of days above $0{ }^{\circ} \mathrm{C}$ when invertebrates could be metabolically active. No long-term, continuous records of soil moisture are available to assess the influence of the decadal cooling trend on soil water, but cooling is also likely to have changed the number of days when sufficient availability of liquid water permits metabolic activity of soil invertebrates (e.g. Treonis et al., 2000). 

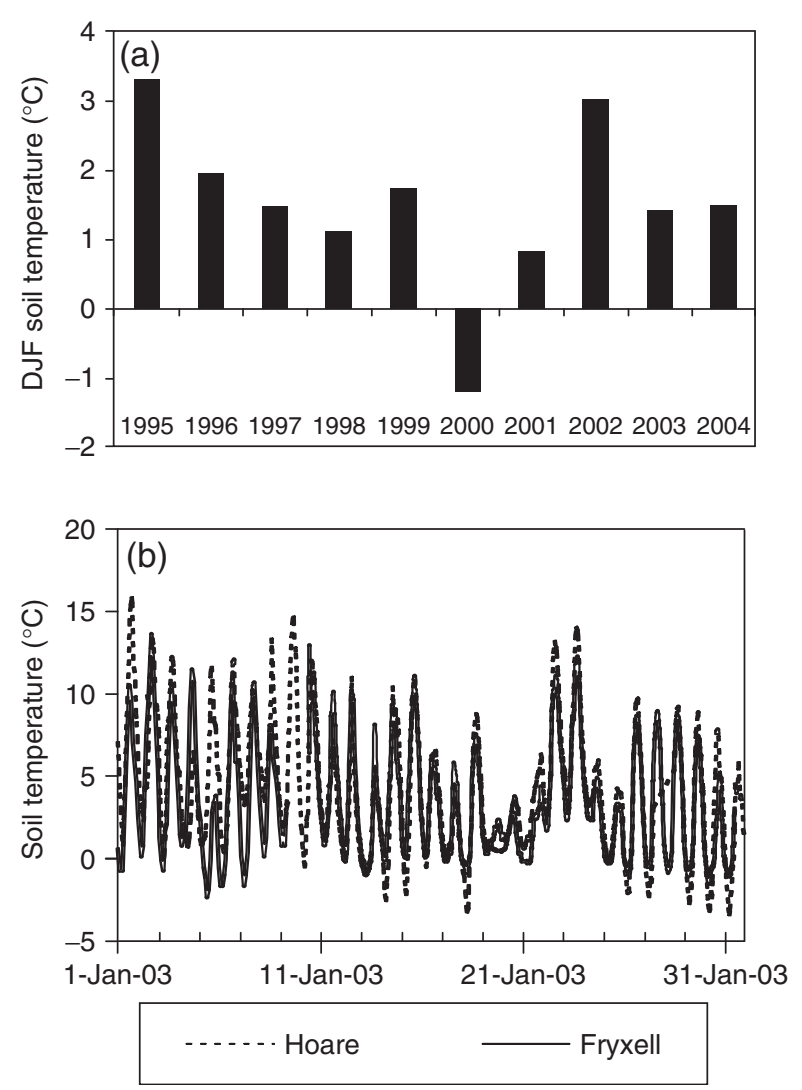

Fig. 2 Mean summer (a) and diel (b) variations in soil temperature $\left({ }^{\circ} \mathrm{C}\right)$ at $5 \mathrm{~cm}$ depth for study sites located near Lake Hoare (a, b) and Lake Fryxell (b) in Taylor Valley, Antarctica. Diel observations of temperatures (b) in soil plots near Lake Hoare are indicated with dashed lines, and the solid line represents temperature in soil plots near Lake Fryxell.

\section{Carbon cycling}

Tracer $\left({ }^{13} \mathrm{C}\right.$-ammended sugar solutions) and control (water only) solutions were added to open-top, intact 1-L volume soil chambers in the field adjacent to longterm experiments in the Lake Fryxell and Lake Hoare basins of Taylor Valley. Before the establishment of the ${ }^{13} \mathrm{C}$-tracer experiment, undisturbed pretreatment soils ( $n=5$ per site) were collected for quantification of initial nematode abundance, microbial biomass, and soil chemistry from within $1 \mathrm{~m}$ of the tracer soil chambers. Control ( $n=5$ per site) and tracer-amended $(n=5$ per site) soil plots were randomly assigned to plots at each experimental site. Control treatments consisted of $100 \mathrm{~mL}$ deionized $\mathrm{H}_{2} \mathrm{O} \mathrm{kg} \mathrm{soil}{ }^{-1}$. Tracer plots received a ${ }^{13} \mathrm{C}$-mannitol (a simple alcohol-sugar derivative of mannose, a common algal sugar) solution of $100 \mathrm{mg}$ 4.4 atom $\%{ }^{13} \mathrm{C}$ in $100 \mathrm{~mL}$ deionized $\mathrm{H}_{2} \mathrm{O}$, which increased the soil organic $\mathrm{C}$ pool by an average of $30 \%$ relative to pretreatment $\left(t_{0}\right)$ soils. We harvested whole open-top soil chambers on day 21 of the experiment and processed control and tracer-amended soils at the Crary Laboratory, McMurdo Station, within $48 \mathrm{~h}$ of collection. We extracted live nematodes from each plot using the Baermann funnel procedure (Poinar, 1983) rather than the modified sucrose extraction technique described earlier so that $C$ contamination from sucrose would not interfere with the estimation of ${ }^{13} \mathrm{C}$-tracer recovery. A minimum of 100 nematodes were hand-picked from each extraction under a low power $(\times 25)$ dissection scope, air-dried in a desiccator, and weighed before determination of ${ }^{13} \mathrm{C}$-tracer recovery.

Total $\mathrm{C}$ assimilation was estimated from the observed nematode populations and fractional abundance of ${ }^{13} \mathrm{C}$ in the nematode biomass. Fractional abundance, $F=\left({ }^{13} \mathrm{C} /{ }^{12} \mathrm{C}\right)$, of labeled and unlabeled nematodes was determined on a Thermo-Finnigan mass spectrometer (Thermo Fisher Scientific, Waltham, MA, USA) at the Kansas State University (Manhattan, KS, USA) stable isotope laboratory. Fractional abundances $(F)$ of the samples were converted to $C$ assimilation rates using the following equations (Boutton, 1991):

$$
\text { atom } \% \text { excess }{ }^{13} \mathrm{C}_{\text {sample }}=\left(F_{\text {postdose }}-F_{\mathrm{t}_{0}}\right) \times 100 \text {, }
$$

$$
\begin{aligned}
\mu \text { mol excess }{ }^{13} \mathrm{C}_{\text {sample }}= & \left(\mu \mathrm{mol}_{\text {sample }}\right) \\
& \times\left(\text { atom } \% \text { excess }{ }^{13} \mathrm{C}_{\text {sample }}\right)
\end{aligned}
$$

$\%$ dose absorbed $=\frac{\left(\mu \text { mol excess }{ }^{13} \mathrm{C}_{\text {sample }}\right)}{\left(\mu \mathrm{mol}^{13} \mathrm{C}_{\text {dose }}\right)}$

$$
\begin{aligned}
{ }^{13} \mathrm{C} \text { assimilation }= & \frac{\% \text { dose absorbed }}{\text { number of nematodes in sample }} \\
& \times \text { organisms kg }{ }^{-1} \times 100 \mathrm{mgC},
\end{aligned}
$$

where postdose refers to the samples collected and extracted after incubation with the ${ }^{13} \mathrm{C}$ mannitol, and $t_{0}$ are the untreated samples collected at the initiation of the experiment. The number of nematodes per kg dry soil was determined independently using the sucrosecentrifugation technique described earlier. We extrapolated rates of nematode $C$ assimilation to estimates of total C flux through nematode biomass, using a $22 \%$ assimilation efficiency based on parameters developed for bacteria-feeding nematodes in the Detrital Food Web Model (Hunt et al., 1987; Hunt \& Wall, 2002):

$$
\text { Nematode C flux }=\frac{{ }^{13} \text { C assimilation }}{\text { assimilation efficiency }}
$$

We measured total ecosystem $\mathrm{CO}_{2}$ efflux at the Lake Hoare and Lake Fryxell sites using a closed gas 
exchange system (LiCor 6400-09, LiCor Inc., Lincoln, $\mathrm{NE}, \mathrm{USA}$ ) modified to measure small changes in $\mathrm{CO}_{2}$ concentrations above desert pavement surfaces (Parsons et al., 2004). Measurements were made midway through the tracer experiment on gas collection collars inserted approximately $3 \mathrm{~cm}$ into undisturbed desert pavement soils adjacent to control and tracer plots. We report mean soil respiration rates from four cycles of measurements conducted near mid-day for monitoring sites adjacent to the tracer-amended plots.

\section{Statistical analyses}

Statistical analyses (means comparisons and regressions) of nematode communities were made on $\log (x+1)$-transformed estimates of abundance to satisfy assumptions of normality and homogeneity of variance (Sokal \& Rohlf, 1995). Treatment means ( $t_{0}$, control and substrate addition) were compared within each site using one-way analysis of variance. Comparisons of means between sites were made with a Student's $t$-test. Regression analyses were performed in JMP for estimation of variance components explained by soil factors.

\section{Results}

Soils from the Lake Fryxell study site contained higher levels of soil water and C, and marginally greater concentrations of chlorophyll $a$ relative to those collected from near Lake Hoare at the initiation of the study (Table 1). Associated with these soil conditions, Fryxell basin soils hosted larger populations, and had greater frequency of occurrence of soil nematodes, which contributed to significantly higher rates of soil respiration (i.e. greater soil $\mathrm{CO}_{2}$ efflux; Table 1). These results are consistent with previous descriptions of these sites that have shown habitat suitability in soils from the Lake Fryxell basin to be superior relative to the Lake Hoare basin (Virginia \& Wall, 1999; Barrett et al., 2004).

\section{Soil temperature}

The 10-year mean summer $( \pm \mathrm{SD})$ surface soil temperature $(0-5 \mathrm{~cm})$ at the Lake Hoare study site was $1.52{ }^{\circ} \mathrm{C}$ $( \pm 1.24)$, with an average of 65 degree days above $0{ }^{\circ} \mathrm{C}$ per year. Summer temperatures were calculated from average daily December, January, and February climate records (see 'Materials and methods'). Two trends are notable in these long-term summer soil temperature records (Fig. 2a): a decline in summer soil temperatures between 1995 and 2001 (consistent with a contemporaneous record of air temperatures reported by Doran et al., 2002b), and above-average summer temperatures in 2002 , followed by average summer temperatures in

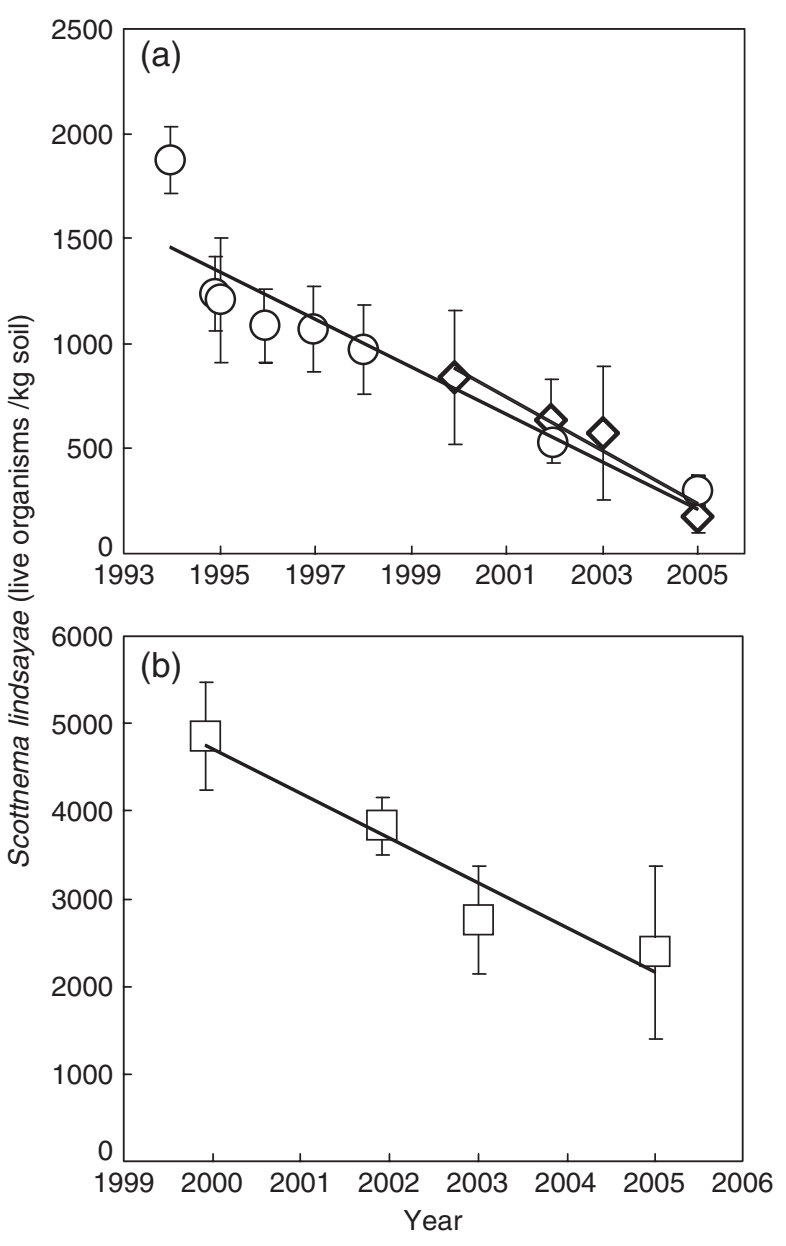

Fig. 3 Decline in populations of Scottnema lindsayae (mean $\pm \mathrm{SE}$ ) on the south side of Lake Hoare (a) and Lake Fryxell (b). Open circles represent means of eight replicate samples collected from long-term monitoring plots near Lake Hoare between 1993 and 2005 (a). Diamonds and squares represent means of six replicate samples collected from monitoring plots near Lake Hoare and Lake Fryxell, respectively, between 1999 and 2005 (a, b).

2003 and 2004. The regression of summer temperatures for the period 1995-2001 is $y=-0.48 x+3.25, R^{2}=0.58$, $P=0.046$. The mean monthly ( $\pm 1 \mathrm{SD}$ ) soil temperatures for January 2003 were $3.3( \pm 3.4)$ and $4.2( \pm 4.0)^{\circ} \mathrm{C}$ at the Fryxell and Hoare sites, respectively (the 10-year mean January soil temperature at Lake Hoare is $3.9 \pm 0.9^{\circ} \mathrm{C}$ ). These observed temperatures amounted to an average of 25 degree days above $0{ }^{\circ} \mathrm{C}$ for the month of January at both sites.

\section{Long-term trends in nematode populations}

Populations (organisms $/ \mathrm{kg}$ soil) of the dominant soil organism, S. lindsayae, declined significantly in all three monitoring sites (Fig. 3). The regression for the longterm decline in S. lindsayae abundance spanning 1993- 
Table 2 Mean $( \pm \mathrm{SD})$ microbial biomass $\mathrm{C}$ and nematode abundance for control (+ water) and substrate-amended $\left(+{ }^{13} \mathrm{C}\right.$ mannitol) plots at two locations in Taylor Valley

\begin{tabular}{|c|c|c|c|}
\hline Variable & Treatment & Fryxell & Hoare \\
\hline \multirow[t]{2}{*}{ Microbial biomass carbon $\left(\mathrm{mg} \mathrm{C} \mathrm{kg}\right.$ soi $\left.\mathrm{l}^{-1}\right)$} & Control (+ water) & $8.6 \pm 2.6$ & $7.4 \pm 2.1$ \\
\hline & Substrate amended & $20.5 \pm 15.5$ & $7.9 \pm 3.8$ \\
\hline \multirow[t]{2}{*}{ Total viable Scottnema lindsayae (no. of organisms kg soil ${ }^{-1}$ ) } & Control (+ water) & $1069 \pm 819$ & $435 \pm 232$ \\
\hline & Substrate amended & $2101 \pm 984$ & $388 \pm 232$ \\
\hline \multirow[t]{2}{*}{ Total viable Eudorylaimus antarcticus (no. of organisms kg soil ${ }^{-1}$ ) } & Control (+ water) & $29 \pm 12$ & $10 \pm 4$ \\
\hline & Substrate amended & $72 \pm 33$ & $10 \pm 6$ \\
\hline
\end{tabular}

2005 is $y=-0.06 x+3.26, R^{2}=0.96, P=0.00002$, with an untransformed slope of -114 nematodes $\mathrm{yr}^{-1}$ (Fig. 3a). The regressions for the decline in S. lindsayae at the additional Fryxell and Hoare sites (Fig. 3a and b), where data have been collected from 1999 to 2005, are $y=-0.064 x+3.74, R^{2}=0.94, P=0.028$, and $y=-0.093 x$ $+3.14, R^{2}=0.68, P=0.017$, respectively. Untransformed slopes for these regressions are -508 and -127 nematodes $\mathrm{yr}^{-1}$ for the Lake Fryxell and Lake Hoare sites, respectively.

\section{Soil carbon cycling}

Dry valley soils occur on poorly developed tills and have very low organic matter content, $0.51 \pm 0.10$ and $0.27 \pm 0.11 \mathrm{~g} \mathrm{C} \mathrm{kg}^{-1}$ in the Fryxell and Hoare sites, respectively (Table 1). Observed rates of soil respiration were low $\left(0.01-0.30 \mu \mathrm{mol} \mathrm{CO} \mathrm{C}^{-2} \mathrm{~s}^{-1}\right)$, but within the range of previously reported values (Burkins et al., 2001; Parsons et al., 2004; Elberling et al., 2006). Soil respiration was almost fourfold higher at the Lake Fryxell site than at Lake Hoare (Table 1).

Increases in nematode abundance and microbial biomass following addition of ${ }^{13} \mathrm{C}$-mannitol treatments in soil plots were not significant, although they were notable in the Lake Fryxell site where the abundance of S. lindsayae and E. antarcticus increased by 100-140\% in substrate-amended plots after the 21-day incubation (Table 2). Most of this increase in the $S$. lindsayae population was due to a higher recruitment of juvenile organisms (data not shown).

Significant differences among the $\delta^{13} \mathrm{C}$ of nematodes extracted from ${ }^{13} \mathrm{C}$-mannitol-amended soils relative to nematodes extracted from control and pretreatment soils are evidence of microbial uptake of the ${ }^{13} \mathrm{C}$ tracer and assimilation by nematodes (Table 3). Nematodes collected from tracer plots in the Fryxell site were enriched in ${ }^{13} \mathrm{C}$ relative to $t_{0}$ and control plots by $>38 \%$ (one-way ANOVA: $F=18.14, P<0.001$ ). Nematodes collected from tracer plots from the Hoare site were enriched relative to $t_{0}$ and control plots by $27 \%$ (one-way ANOVA: $F=4.85, P<0.037$ ). Enrichment of ${ }^{13} \mathrm{C}$
Table 3 Tracer recovery, $\mathrm{C}$ assimilation, total $\mathrm{C}$ efflux, and estimated $C$ flux associated with nematode communities at two sites in Taylor Valley, Antarctica

\begin{tabular}{|c|c|c|}
\hline Variable & Fryxell & Hoare \\
\hline $\begin{array}{l}{ }^{13} \mathrm{C} \text { of nematodes collected } \\
\text { at } t_{0}\left(\delta^{13} \mathrm{C} \% \mathrm{o}\right)\end{array}$ & $-27.6 \pm 0.8^{\mathrm{b}^{*}}$ & $-29.5 \pm 0.6^{\mathrm{b}}$ \\
\hline $\begin{array}{l}{ }^{13} \mathrm{C} \text { of nematodes collected } \\
\text { from control plots }\left(\delta^{13} \mathrm{C} \%\right)\end{array}$ & $-26.0 \pm 2.3^{\mathrm{b}}$ & $-27.1 \pm 4.4^{\mathrm{b}}$ \\
\hline $\begin{array}{l}{ }^{13} \mathrm{C} \text { of nematodes collected } \\
\text { from tracer plots }\left(\delta^{13} \mathrm{C} \%\right)\end{array}$ & $11.9 \pm 5.4^{\mathrm{a}}$ & $1.3 \pm 7.5^{\mathrm{a}}$ \\
\hline $\begin{array}{l}\text { Nematode } C \text { assimilation } \\
\quad\left(\mu \mathrm{g} C \mathrm{~kg} \mathrm{soil}^{-1} \text { day }^{-1}\right)\end{array}$ & $8.6 \pm 2.4^{a}$ & $1.8 \pm 0.74^{\mathrm{b}}$ \\
\hline $\begin{array}{l}\text { Nematode } C \text { flux } \\
\quad\left(\mu \mathrm{g} C \mathrm{~kg} \mathrm{soil}{ }^{-1} \text { day }^{-1}\right)\end{array}$ & $39.0 \pm 10.74^{\mathrm{a}}$ & $8.3 \pm 3.38^{\mathrm{b}}$ \\
\hline
\end{tabular}

${ }^{*}$ Mean \pm 1 standard deviation.

Significant $(P<0.05)$ differences in ${ }^{13} \mathrm{C}$ content among assay conditions $\left(t_{0}\right.$, control and tracer) by one-way ANOVA are indicated by different superscript letters.

Significant comparisons of nematode $C$ assimilation between sites by one-tailed Student's $t$-test are indicated by superscript different letters.

in nematodes extracted from Fryxell soils was more than $10 \%$ greater than enrichment in nematodes extracted from Hoare soils, which contributed to higher estimates of $\mathrm{C}$ assimilation rates by nematodes in Fryxell plots relative to Hoare (two-tailed $t$-test: $P=0.042$; Table 3).

\section{Discussion}

Recent climate cooling in the McMurdo Dry Valleys has contributed to significant responses in aquatic and terrestrial ecosystems (Doran et al., 2002b; Esposito et al., 2006). Primary productivity in Taylor Valley lakes decreased by $6-9 \% \mathrm{yr}^{-1}$ through the 1990s following increases in ice thickness and decreases in the penetration of solar irradiance (Doran et al., 2002b). Decreases in soil nematode populations coincided with this cooling of the dry valley region. Our data extend the trend initially reported by Doran et al. (2002b) by 7 years, and to additional sites in Taylor Valley (Fig. 3). This trend 
illustrates an overall decline of $65 \%$ in populations of the dominant soil organism, the microbivorous nematode, S. lindsayae. Similar, low-diversity soil communities on the Antarctic Peninsula have also exhibited sensitivity to changes in soil climate following temperature and water manipulations (Convey et al., 2002). Although this and related studies demonstrated declines in soil biota following climate warming, the results emphasized the interactive effect of temperature and moisture availability on soil biota (Convey et al., 2002; Newsham \& Garstecki, 2007) and, together with our data, support the conclusion that even modest changes in climate (warming or cooling) can have significant influences over soil communities. In Antarctic ecosystems where species diversity and hence functional redundancy is low, ecosystem responses to variability in species composition are influenced by a few key species (e.g. Bohn \& Amundsen, 2004). Thus, even small variation in communities or abundance of key species could elicit significant changes in ecosystem functioning, as observed in our study.

In contrast to the aquatic ecosystems of Taylor Valley where the proximate effects of cooling are associated with changes in the balance of liquid water and ice (i.e. glacial melt, stream flow, ice thickness in lakes), the influence of cooling on soils may be due to direct changes in the thermal regime, as well as to changes in liquid water availability. Thus, the decadal-scale decreases in nematode populations may be attributed to decreases in soil water content hypothesized to accompanying regional cooling, and/or declines in degree days above $0^{\circ} \mathrm{C}$, and resulting limitations over reproduction and recruitment. Melting of ground-ice has been shown to occur during the austral summer (Lyons et al., 2005), and it logically follows that cooling conditions would limit ice-melt and reduce soil moisture conditions. For example, long-term climate variation in Eastern Antarctica has contributed to significant changes in snowfall and moisture balance (Hodgson et al., 2006). Similar changes in climate and moisture balance are linked to changes in soil biota in maritime Antarctica (Hodgson \& Convey, 2005).

Antarctic nematodes are well adapted to these climate extremes through anhydrobiosis (Treonis et al., 2000), a survival strategy induced by desiccation where organisms enter a dry, metabolically inactive state as a protection against environmental stress (Crowe \& Maden, 1975). Antarctic nematodes spend a significant proportion of their lifespan in this inactive state, likely spanning multiple years, because the average number of degree days above $0^{\circ} \mathrm{C}$ is considerably less than the time required to complete heir lifecycle (estimated at 218 days; Overhoff et al., 1993). Under cooling conditions with fewer days capable of supporting metabolic activity, nematode populations would have limited opportunity to reproduce, while natural rates of mortality would result in relatively constant decreases in population not balanced by recruitment. Thus, the decadal scale decline may not be a physiological response to temperature, but rather a temporal constraint imposed by the limited number of degree days above $0{ }^{\circ} \mathrm{C}$, which restricts opportunity for reproduction. Moreover, anhydrobiosis confers an inherent hysteresis into Antarctic nematode communities. Population levels in any given year may be a legacy of the climate of the previous year, even under warm contemporary conditions, particularly if previously cold soils are also dry. As a consequence, recovery of Taylor Valley nematode population levels to pre-1993 conditions may require multiple years of warm conditions.

\section{Carbon assimilation}

The variation in $C$ assimilation by nematodes observed at the site level (Table 3) in this study reflected the greater abundance of nematodes and a higher $\mathrm{C}$ assimilation per individual nematode at the Fryxell site (Table 2), where rates of soil respiration, soil organic $C$, and moisture were significantly greater than in the Hoare location (Table 1). Similarly, differences observed in the rates of nematode population decline between sites may be due to differences in soil conditions (e.g. $C$ and water availability) and different population levels before the initiation of data collection. Differences in microclimate may also contribute to this variation. For example, the site near Lake Fryxell typically has greater relative humidity (Doran et al., 2002a) and grab-samples from numerous studies conducted over multiple years at different times of the summer have exhibited higher moisture content (Virginia \& Wall, 1999; Barrett et al., 2004; Parsons et al., 2004), although the lack of more detailed microclimate records, especially water availability, prohibits drawing conclusions about differences in soil climate conditions between the two sites.

At both sites, nematodes accounted for a measurable fraction of the total soil $\mathrm{C}$ efflux (i.e. total soil respiration), exceeding $7 \%$ for the most biologically active soils in the Fryxell basin. This rate of $\mathrm{C}$ flux through nematode biomass is highly disproportionate to their small contribution to the total $\mathrm{C}$ budget (i.e. $0.025 \%$ of soil organic C). Because microbivorous nematodes have been shown to stimulate microbial growth and turnover (Ingham et al., 1985; Bardgett et al., 1999; Ekschmitt et al., 1999), it is likely that nematode influence over soil C dynamics in the McMurdo Dry Valleys surpasses this estimate (i.e. 7\%) through their combined influence on microbial dynamics and nutrient mineralization. These proportions of $\mathrm{C}$ cycling contributed by the dry valley 
nematode community to the total soil flux are comparable to observations of invertebrate contributions to energy flow in temperate ecosystems with much more diverse and higher biomass metazoan communities (Ferris et al., 1995; Verschoor, 2002; Schroter et al., 2003; Cebrian, 2004). For example, we report that nematodes contributed 2-6 ng C nematode ${ }^{-1}$ day $^{-1}$ or $2-7 \%$ of the total heterotrophic C flux in Taylor Valley soils, compared with 2-3ng N nematode ${ }^{-1}$ day $^{-1}$ for Aphelenchus spp. isolated from agricultural soils in California, USA (Chen \& Ferris, 1999), 2-5\% of nitrogen mineralization in European grasslands (Verschoor, 2002), and $7-13 \%$ of total C mineralization by total soil faunal communities in a European forest food web (Schroter et al., 2003). Thus, the contribution of one to two species of Antarctic nematodes to ecosystem functioning of dry valley soils is in the same order of magnitude of rates of nematode activity in highly productive and species-diverse temperate ecosystems.

\section{Species-specific variation in carbon cycling}

Carbon assimilation increased as a nonlinear function of nematode abundance (Fig. 4). The log-fit between C assimilation and nematode abundance is $y=4.96 \ln (x)$ 26.93, $R^{2}=0.93$, for one-species communities and $y=2.40 \ln (x)-12.60, R^{2}=0.98$, for two-species communities (Fig. 4). It is somewhat surprising that this relationship is not linear considering that the influence of individual organisms upon $C$ assimilation would be expected to be additive, that is to say that the relationship between assimilation and abundance should be

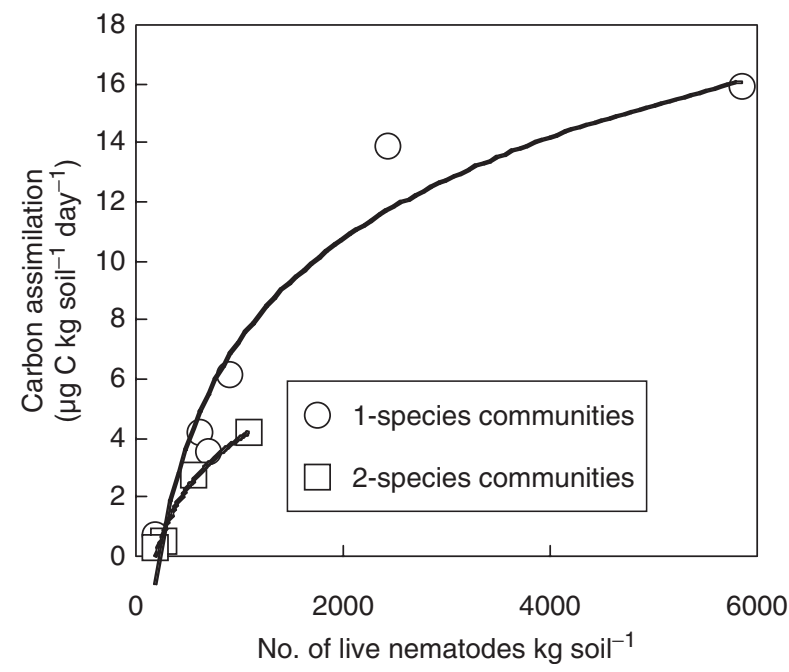

Fig. 4 Carbon assimilation rates of Antarctic nematodes (calculated from ${ }^{13} \mathrm{C}$ recovery given in Table 3 ) vs. abundance (organisms kg soil ${ }^{-1}$ ) of one-species (open circles) and two-species (open squares) communities. linear, especially in an ecosystem where biotic interactions (e.g. competition) are typically considered minimal (Hogg et al., 2006). This nonlinear response could be influenced by a number of ecological factors including demographic variation in nematode populations which could change $C$ assimilation because of biomass-metabolism scaling relationships (West et al., 2003), or density-dependent interactions (Vetter et al., 2004), limiting access to microbial substrate in higher populations, especially if this influenced access to ${ }^{13} \mathrm{C}$-labeled microbes.

E. antarcticus, a larger organism than S. lindsayae, 0.92 compared with $0.26 \mu \mathrm{g}_{\text {dry weight individual }}{ }^{-1}$ (Freckman \& Virginia, 1997), was present in half of the soil plots where it comprised $14 \%$ of the total nematode populations (Table 1). This larger species might be expected to exert a significant influence over community metabolism despite its lower abundance. However, the $\mathrm{C}$ assimilation rates for nematodes collected from single-species ( $S$. lindsayae) and two-species (S. lindsayae $+E$. antarcticus) communities were similar over the wide range of nematode abundances (approximately $100-1000$ nematodes $\mathrm{kg} \mathrm{soil}^{-1}$ ). This result suggests that $E$. antarcticus does not interact with microbial populations in the same manner as S. lindsayae. This finding is consistent with presumed differences in their feeding preferences; $S$. lindsayae is a microbivore and E. antarcticus has been observed to consume algae (Wall, 2007), which would not incorporate the ${ }^{13} \mathrm{C}$ label. As a result, tracer recovery increased as a function of total nematode abundance and was driven largely by numbers of $S$. lindsayae, regardless of richness or community type (Fig. 4).

Similar results have been reported in other studies from temperate environments where abundance of particular species (Smith \& Knapp, 2003; Cole et al., 2004; Dangles \& Malmqvist, 2004) or functional differences among species (Heemsbergen et al., 2004) were more important than the influence of species richness. For example, Dangles \& Malmqvist (2004) reported that shifts in abundances can have effects on ecosystem functioning that are as great as those from shifts in species richness and suggest that biodiversity-ecosystem functioning relationships may be driven by dominant species in soil ecosystems, as our results suggest. Other biotic interactions, such as competition for resources, mutual inhibition, predation or density dependence in general, may complicate diversity-functioning relationships (Vetter et al., 2004).

The simple two-species community we investigated does not provide an adequate range of diversity to evaluate the influence of species richness on ecosystem functioning. However, the data from the one-species communities demonstrate that the dominant species 
(S. lindsayae) is responsible for a high proportion of metazoan-mediated $\mathrm{C}$ cycling observed in dry valley soil ecosystems. In some ecosystems, certain species (i.e. keystone species) play more critical roles in ecosystem functioning, because they possess a particular behavior or trait (Mills et al., 1993). Soil food webs are generally considered less prone to species-specific effects than aboveground ecosystems because they are characterized by a high degree of species diversity and functional redundancy (Liiri et al., 2002). Our data demonstrate that in a soil ecosystem with low taxonomic, phylogenetic, and functional diversity, a single species plays a critical role in the $\mathrm{C}$ cycle and by implication, food web dynamics. A decline in such a key soil species, as has been observed over the past decade (Doran et al., 2000a), would be expected to elicit strong effects on ecosystemlevel C cycling.

The microscopic nature of soil fauna belies the fact that these organisms are responsible for a large proportion of the energy flow and nutrient mineralization in terrestrial ecosystems (Ingham et al., 1985; Ferris et al., 1995; Verschoor, 2002; Schroter et al., 2003; Cebrian, 2004). Even the lowest estimates of nematode activity reported here are significant considering that dry valley soils have traditionally been considered inactive, even 'aseptic' environments (Priscu, 1999). This study and other recent evidence demonstrate that cold desert food webs are not only active but are also sensitive to climate change (Doran et al., 2002b; Hodgson \& Convey, 2005; Esposito et al., 2006). Considering the dominance of $S$. lindsayae in dry valley soil food webs, continuing declines in population levels in response to climate change are expected to alter $\mathrm{C}$ cycling and influence soil microbial communities and associated ecosystem functioning. The $65 \%$ decline in S. lindsayae populations is associated with a $32 \%$ loss of function in $\mathrm{C}$ cycling as inferred by the relationships between nematode abundance and $\mathrm{C}$ assimilation shown in Fig. 4. This nonlinear trend suggests that further declines may elicit increasingly large changes in $C$ cycling. An understanding of $C$ cycling in these soils and how they respond to species decline or loss is fundamental to predicting the response of Antarctic ecosystem functioning to climate change.

\section{Conclusions}

Studies in high-diversity ecosystems have demonstrated functional redundancy in biodiversity-mediated ecosystem processes and consequently little alteration of ecosystem functioning following declines in species diversity. However, low-diversity ecosystems, such as deserts, cover much of the Earth's surface. We show that in a low-diversity polar desert, a single nematode species is responsible for a significant portion of $\mathrm{C}$ cycling. A decline in abundance of this nematode, associated with regional climate change, suggests that alteration of soil communities in low-diversity ecosystems may significantly alter the ecosystem processes.

\section{Acknowledgements}

This work was supported by the McMurdo LTER program (National Science Foundation Grant OPP-0096250). J. Nkem, A. Parsons, and D. Porazinska contributed to the description of invertebrate communities. Logistical support was provided by Antarctic Support Associates, Raytheon Polar Services Corporation, and Petroleum Helicopters Inc.

\section{References}

Adams BJ, Bardgett R, Ayres DE et al. (2006) Diversity and distribution of Victoria Land biota. Soil Biology and Biochemistry, 38, 3003-3018.

Andrén O, Balandreau J (1999) Biodiversity and soil functioning - from black box to can of worms? Applied Soil Ecology, 13, 105-108.

Anisimov OA, Vaughan DG, Callaghan T et al. (2007) Polar regions (Arctic and Antarctic). In: Climate Change 2007: Impacts, Adaptation and Vulnerability. Contribution of Working group II to the Fourth Assessment Report of the Intergovernmental Panel on Climate Change (eds Parry ML, Canziani OF, Palutikof JP, van der Linden PJ, Hanson CE), pp. 63-685. Cambridge University Press, Cambridge.

Bardgett RD, Cook R, Yeates GW, Denton CS (1999) The influence of nematodes on below-ground process in grassland ecosystems. Plant and Soil, 212, 23-33.

Barrett JE, Virginia RA, Wall DH, Cary SC, Adams BJ, Hacker AL, Aislabie JM (2006) Co-variation in soil biodiversity and biogeochemistry in northern and southern Victoria Land, Antarctica. Antarctic Science, 18, 535-548.

Barrett JE, Wall DH, Virginia RA, Parsons AN, Powers LE, Burkins MB (2004) Variation in biogeochemistry and soil biodiversity across spatial scales in a polar desert ecosystem. Ecology, 85, 3105-3118.

Bohn T, Amundsen PA (2004) Ecological interactions and evolution: forgotten parts of biodiversity? BioScience, 54, 804-805.

Boutton TW (1991) Tracer studies with ${ }^{13} \mathrm{C}$-enriched substrates: humans and large animals. In: Carbon Isotope Techniques (eds Coleman DC, Fry B), pp. 219-242. Academic Press, San Diego.

Bradford MA, Jones TH, Bardgett RD et al. (2002) Impacts of soil faunal community composition on model grassland ecosystems. Science, 298, 615-618.

Burkins MB, Virginia RA, Wall DH (2001) Organic carbon cycling in Taylor Valley, Antarctica: quantifying soil reservoirs and soil respiration. Global Change Biology, 7, 113-125.

Cebrian J (2004) Role of first-order consumers in ecosystem carbon flow. Ecology Letters, 7, 232-240.

Chen J, Ferris H (1999) The effects of nematode grazing on nitrogen mineralization during fungal decomposition of organic matter. Soil Biology and Biochemistry, 31, 1265-1279. 
Cheng WX, Virginia RA (1993) Measurement of microbial biomass in arctic tundra soils using fumigation extraction and substrate-induced respiration procedures. Soil Biology and Biochemistry, 25, 135-141.

Cole L, Dromph KM, Boaglio V, Bardgett RD (2004) Effect of density and species richness of soil mesofauna on nutrient mineralisation and plant growth. Biology and Fertility of Soil, 39, 337-343.

Convey P, McInnes SJ (2005) Exceptional tardigrade-dominated ecosystems in Ellsworth Land, Antarctica. Ecology, 86, 519-527.

Convey P, Pugh PJA, Jackson C, Murray AW, Ruhland CT, Xiong FS, Day TA (2002) Response of Antarctic terrestrial microarthropods to long-term climate manipulations. Ecology, 83, 3130-3140.

Crowe JH, Maden KAC (1975) Anhydrobiosis in nematodes evaporative water-loss and survival. Journal of Experimental Zoology, 193, 323-334.

Dangles O, Malmqvist B (2004) Species richness-decomposition relationships depend on species dominance. Ecology Letters, 7, 395-402.

Doran PT, McKay CP, Clow GD, Dana GL, Fountain AG, Nylen T, Lyons WB (2002a) Valley floor climate observations from the McMurdo Dry Valleys, Antarctica, 1986-2000. Journal of Geophysical Research, 107, 4772-4784.

Doran PT, Priscu JC, Lyons WB et al. (2002b) Antarctic climate cooling and terrestrial ecosystem response. Nature, 415, 517-520.

Ekschmitt K, Bakonyi G, Bongers M et al. (1999) Effects of the nematofauna on microbial energy and matter transformation rates in European grassland soils. Plant and Soil, 212, 45-61.

Elberling B, Gregorich EG, Hopkins DW, Sparrow AD, Novis P, Greenfield LG (2006) Distribution and dynamics of soil organic matter in an Antarctic dry valley. Soil Biology and Biochemistry, 38, 3095-3106.

Esposito RMM, Horn SL, McKnight DM et al. (2006) Antarctic climate cooling and response of diatoms in glacial meltwater streams. Geophysical Research Letters, 33, Art. No. L07406.

Ferris H, Lau S, Venette R (1995) Population energetics of bacterialfeeding nematodes - respiration and metabolic rates based on $\mathrm{CO}_{2}$ production. Soil Biology and Biochemistry, 27, 319-330.

Fitter AH, Gilligan CA, Hollingworth K, Kleczkowski A, Twyman RM, Pitchford JW (2005) Biodiversity and ecosystem function in soil. Functional Ecology, 19, 369-377.

Freckman DW, Virginia RA (1997) Low-diversity Antarctic soil nematode communities: distribution and response to disturbance. Ecology, 78, 363-369.

Heemsbergen DA, Berg MP, Loreau M, van Hal JR, Faber JH, Verhoef HA (2004) Biodiversity effects on soil processes explained by interspecific functional dissimilarity. Science, 306, 1019-1020.

Hodgson DA, Convey P (2005) A 7000-year record of oribatid mite communities on a maritime-Antarctic island: responses to climate change. Arctic, Antarctic and Alpine Research, 37, 239-245.

Hodgson DA, Roberts D, McMinn A, Verleyen E, Terry B, Corbett C, Vyverman W (2006) Recent rapid salinity rise in three East Antarctic lakes. Journal of Paleolimnology, 36, 385-406.

Hogg ID, Cary SC, Convey P et al. (2006) Biotic interactions in Antarctic terrestrial ecosystems: are they a factor? Soil Biology and Biochemistry, 38, 3035-3040.
Hunt HW, Coleman DC, Ingham ER et al. (1987) The detrital food web in a shortgrass prairie. Biology and Fertility of Soil, 3, 57-68.

Hunt HW, Wall DH (2002) Modeling the effects of loss of soil biodiversity on ecosystem function. Global Change Biology, 8, 33-50.

Ingham RE, Trofymow JA, Ingham ER, Coleman DC (1985) Interactions of bacteria, fungi, and their nematode grazers effects on nutrient cycling and plant-growth. Ecological Monographs, 55, 119-140.

Kareiva P, Marvier M (2003) Conserving biodiversity coldspots recent calls to direct conservation funding to the world's biodiversity hotspots may be bad investment advise. American Scientist, 91, 344-351.

Liiri M, Setälä H, Haimi J, Pennanen T, Fritze H (2002) Relationship between soil microarthropod species diversity and plant growth does not change when the system is disturbed. Oikos, 96, 137-149.

Lyons WB, Welch KA, Carey AE et al. (2005) Groundwater seeps in Taylor Valley Antarctica: an example of a decadal subsurface melt event. Annals of Glaciology, 40, 200-206.

Mills LS, Soule ME, Doak DF (1993) The keystone-species concept in ecology and conservation. BioScience, 43, 219-224.

Newsham KK, Garstecki T (2007) Interactive effects of warming and species loss on model Antarctic microbial food webs. Functional Ecology, 21, 577-584.

Nkem JN, Virginia RA, Barrett JE, Wall DH (2006) Salt inhibits nematode colonization in soils of the Antarctic Dry Valleys. Polar Biology, 29, 643-651.

Olff H, Ritchie ME, Prins HHT (2002) Global environmental controls of diversity in large herbivores. Nature, 415, 901-904.

Overhoff A, Freckman DW, Virginia RA (1993) Life cycle of the mocrobivorous Antarctic Dry Valley nematode Scottnema lindsayae (Timm, 1971). Polar Biology, 13, 151-156.

Parsons AN, Barrett JE, Wall DH, Virginia RA (2004) Soil carbon dioxide flux in Antarctic Dry Valley ecosystems. Ecosystems, 7, 286-295.

Poage MA, Barrett JE, Virginia RA, Wall DH (2008) Geochemical control over nematode distribution in soils of the McMurdo Dry Valleys, Antarctica. Arctic, Antarctic and Alpine Research, 40, 119-128.

Poinar GO (1983) The Natural History of Nematodes. Prentice-Hall, Englewood Cliffs, New Jersey.

Priscu JC (1999) Life in the valley of the dead. BioScience, 49, 960. Schroter D, Wolters V, DeRuiter PC (2003) C and N mineralisation in the decomposer food webs of a European forest transect. Oikos, 102, 294-308.

Setälä H, McLean MA (2004) Decomposition rate of organic substrates in relation to the species diversity of soil saprophytic fungi. Oecologia, 139, 98-107.

Smith MD, Knapp AK (2003) Dominant species maintain ecosystem function with non-random species loss. Ecology Letters, 6, 509-517.

Sokal RR, Rohlf FJ (1995) Biometry. WH Freeman and Company, New York.

Spehn EM, Hector A, Joshi J et al. (2005) Ecosystem effects of biodiversity manipulations in European grasslands. Ecological Monographs, 75, 37-63. 
Tilman DA, Reich PB, Knops J, Wedin D, Mielke T, Lehman C (2001) Diversity and productivity in a long-term grassland experiment. Science, 294, 843-845.

Timm RW (1971) Antarctic soil and freshwater nematodes from the McMurdo Sound region. Proceedings of the Helminthological Society of Washington, 38, 42-52.

Treonis AM, Wall DH, Virginia RA (1999) Invertebrate biodiversity in Antarctic Dry Valley soils and sediments. Ecosystems, 2, 482-492.

Treonis AM, Wall DH, Virginia RA (2000) The use of anhydrobiosis by soil nematodes in the Antarctic Dry Valleys. Functional Ecology, 14, 460-467.

Turner J, Colwell S, Marshall G et al. (2005) Antarctic climate change during the last 50 years. International Journal of Climatology, 25, 279-294.

Vaughan DG, Marshall GJ, Connolley WM et al. (2003) Recent rapid regional climate warming on the Antarctic Peninsula. Climate Change, 60, 243-274.

Verschoor BC (2002) Carbon and nitrogen budgets of plantfeeding nematodes in grasslands of different productivity. Applied Soil Ecology, 20, 15-25.

Vetter S, Fox O, Ekschitt K, Wolters V (2004) Limitations of faunal effects on soil carbon flow: density dependence, biotic regula- tion and mutual inhibition. Soil Biology and Biochemistry, 36, 387-397.

Virginia RA, Wall DH (1999) How soils structure communities in the Antarctic Dry Valleys. BioScience, 49, 973-983.

Wall DH (2007) Global change tipping points: above- and belowground biotic interactions in a low diversity ecosystem. Philosophical Transactions of the Royal Society of London. Series B, Biological Sciences, 362, 2291-2306.

Wall DH, Virginia RA (1999) Controls on soil biodiversity: insights from extreme environments. Applied Soil Ecology, 13, 137-150.

Wardle DA, Bardgett RD, Klironomos JN, Setälä H, van der Putten WH, Wall DH (2004) Ecological linkages between aboveground and belowground biota. Science, 304, 1629-1633.

West GB, Savage VM, Gillooly J, Enquist BJ, Woodruff WH, Brown JH (2003) Why does metabolic rate scale with body size? Nature, 421, 713-713.

Witherow RA, Lyons WB, Bertler NAN et al. (2006) The aeolian flux of calcium, chloride and nitrate to the McMurdo Dry Valleys landscape: evidence from snow pit analysis. Antarctic Science, 18, 497-505.

Yeates GW (1970) Two terrestrial nematodes from the McMurdo Sound region Antarctica, with a note on Anaplectus arenicola Killick, 1964. Journal of Helminthology, 44, 27-34. 